\title{
Protein FEV
}

National Cancer Institute

\section{Source}

National Cancer Institute. Protein FEV. NCI Thesaurus. Code C97484.

Protein FEV (238 aa, $\sim 25 \mathrm{kDa}$ ) is encoded by the human FEV gene. This protein may play a role in the repression of transcription. 